\title{
Genetic Analysis of Seed Cotton Yield and its Attributes under Early and Late Plantings
}

\author{
Ezzat E. Mahdy, Atif Abo-Elwafa Ahmed, G.H. Abd El-Zaher*, Mohammed A. Sayed ${ }^{\#}$ \\ and Mohamed. G. Hosein* \\ Agronomy Departmnet, Faculty of Agriculture, Assiut University, Assiut and "Cotton Res. Inst., \\ Agricultural Research Center (ARC), Cairo, Egypt.
}

\begin{abstract}
7 HIS RESEARCH was conducted to study the effects of late planting on the performance of Egyptian cotton sensitivity to environment, and gene actions that controlling seed cotton yield/plant (SCY/P) and related traits. Half diallel crosses of eight Egyptian cotton varieties were evaluated under early and late plantings. The analysis of variance indicated significant $(p \leq 0.01)$ differences among entries (parents and crosses) for most traits. The reduction percentin seed SCY/P caused by the stress of late planting was 17.98 and 18.25 percent for the parents and hybrids; respectively. Stress susceptibility index indicated that five parents were tolerant for SCY/P to late planting. Fifteen out of the 28 hybrids showed tolerance in SCY/P to late planting. The diallel analysis of variance indicated that both additive and dominance effects of genes were involved in the inheritance of all traits. Generally, the regression coefficient " $b_{\mathrm{Wr} / \mathrm{Vr}}$ " and the graphical analysis revealed that the inheritance of seed cotton yield/plant controlled by additive, dominance and epistatic effects of genes. The results of boll weight under the stress of late planting suggested the presence of additive, dominance and epistatic genes interaction. The genetic analysis of number of seeds/boll under late planting indicated no significance of the additive effects of genes "a item", however, the dominance item " $b$ " was significant $(p \leq 0.01)$. The non-additive effects of genes were reflected in the departure of narrow from broad sense heritability. Therefore, pedigree and recurrent selection breeding methods could be effective in isolating lines adapted to late planting.
\end{abstract}

Keywords: Egyptian cotton, Gene action, Late plantings, Seed cotton yield.

\section{Introduction}

Many reports emphasized the adverse effects of late sowing on yield and fiber properties, and mask any genetic improvement in cotton (Bauer et al. 1998; Bange \& Milroy, 2004; Bange et al. 2008 and Pettigrew \& Meredith 2009). The lack of understanding the effects of late sowing on genetics of yield and fiber properties of cotton is a great obstacle in improving new strains of cotton adapted to short-season production. Diallel analysis, as developed by Hayman (1954 and 1958), Jinks (1956) and Jinks \& Hayman (1953), provides full information to identify superior parents and crosses for different traits. Several researchers (Luckett, 1989; Khan et al. 1995; Iqbal \& Khan, 1996; Esmail et al., 1999; Mukhtar et al. 2000; Nadeem \& Azhar, 2004; Basal \& Turgut, 2005; Mohamed et al. 2009; Imran et al. 2012; Kumar et al. 2013; Raza et al. 2013;
Simon et al. 2013; Soomro et al. 2006; Waqar et al. 2015 and Memon et al., 2016) pointed to the importance of genetic studies of the materials before selecting the desirable plant. Azhar \& Khan (2005), Abbas et al. (2008), Abd El-Bary et al. (2008), Zangi et al. (2009), Palv (2009) and Darweesh (2010) reported that GCA effects were highly significant for number of bolls, seed cotton yield and lint percentage. They added that the general combining ability (GCA) variances were greater than specific combining ability (SCA) variances. Mohammed (2010) in G. hirsutum found that boll weight and number of open bolls were influenced by additive gene effects. While, seed cotton yield and number of sympodia were influenced by non-additive gene effects. Dewdar (2011), El-Kadi et al. (2011), Khan et al. (2011), Said (2011), Ali (2013) and Raza et al. (2013) revealed that there were noticeable differences between the parental genotypes for

\#Corresponding author email: mohamed.sayed5@agr.au.edu.eg 
their positive significant GCA effects for most studied traits. In general, the magnitude of GCA mean squares was mostly greater than SCA mean squares expressed as GCA/SCA ratio, indicated that the magnitude of additive and additive $\times$ additive genetic effects were considerable in the inheritance of all characters compared to nonadditive effects. Simon et al. (2013) found that GCA effects were higher than SCA effects for first fruiting nodes, in contrast in the case of days to first flower; suggesting that both additive and non-additive gene effects are playing an important role in inheritance of these characters. The current article was conducted to study the effects of late sowing date on the performance, and get detailed information concerning the genetic control of seed cotton yield/plant, number of bolls/plant, boll weight, seed index and number of seeds/boll of eight parent diallel cross of Egyptian cotton cultivars under early and late sowing dates.

\section{Materials and Methods}

\section{Plant materials}

This research was carried out at Shandaweel Res. Stn. Sohag, Cotton Res. Inst., ARC, during the summers of 2015 and 2016. The basic materials were eight Egyptian cotton varieties belong to $G$. barbadense, L. These varieties are shown in Table 1. The pure seeds of these varieties were obtained from the Cotton Research Institute, Agricultural Research Center at Giza, Egypt. The name, pedigree and the main characteristics of these varieties are presented in Table 1.

TABLE 1. The name, pedigree and the main characteristics of the varieties.

\begin{tabular}{|c|c|c|}
\hline Genotypes & Pedigree & Characteristics \\
\hline Giza 95 & $\begin{array}{l}{[(\mathrm{G} .83 \times(\mathrm{G} .75 \times 5844)) \times} \\
\mathrm{G} .80]\end{array}$ & $\begin{array}{l}\text { A new long-staple cotton variety, characterized by high } \\
\text { yield-, high lint percentage, early maturity and heat } \\
\text { tolerance (cultivated). }\end{array}$ \\
\hline Giza 92 & G84 (G74 x G68) & An extra-long staple variety, (cultivated). \\
\hline Giza 90 & Giza $83 \times$ Dandara & $\begin{array}{l}\text { Long-staple variety for upper Egypt, high yield and lint } \\
\text { percentage (cultivated). }\end{array}$ \\
\hline Giza90×Aus & Giza $90 \times$ Australian & Characterized by high yield and earliness (cultivated). \\
\hline Giza 87 & $(\mathrm{G} .77 \times \mathrm{G} .45 \mathrm{~A})$ & An extra-long staple (cultivated). \\
\hline Giza 86 & $(\mathrm{G} .77 \times$ G.45B $)$ & Long-staple variety, characterized by high yield \\
\hline Giza 80 & G. $66 \times$ G. 73 & $\begin{array}{l}\text { Long-staple variety,characterized by high yield and lint } \\
\text { percentage (cultivated). }\end{array}$ \\
\hline Giza 45 & G. $7 \times$ G. 28 & An extra-long staple variety, (obsolete). \\
\hline
\end{tabular}

Reduction $\%=($ early-late $) /$ early.

\section{Experimental design and field conditions \\ First season (2015)}

The eight varieties were crossed in all possible combinations excluding reciprocals.

Second season (2016)

The parents and the 28 hybrids were sown on the $29^{\text {th }}$ of March (early plating date) and on the $1^{\text {st }}$ of May (late plating date) in a randomized complete block design with three replications for each treatment. Each plot consisted of one row, four-meterslong, $0.6 \mathrm{~m}$ apart and $40 \mathrm{~cm}$ between hills within a row. After full emergence, seedlings were thinned to one plant per hill. The recommended cultural practices were adopted throughout the growing season. The following data were recorded on each plot: 1) The seedcotton yield/plant (SCY/P) was determined by dividing the total seed cotton yield of the two pickings by the number of plants. 2) The number of bolls/plant (NB/P); was counted during the two pickings. 3) The boll weight (BW); was estimated by taking the average weight of 25 bolls picked before the first picking from each plot. 4) The seed index (SI) was determined by weighing 100 seeds. 


\section{Statistical analyses}

The analysis of variance was performed in a randomized complete block design (RCBD) as outlined by Steel \&Torrie (1980). Mean comparisons were calculated using revised L.S.D where :

$$
\text { R L S D } \alpha=\left(\mathrm{t}^{\prime}\right) \alpha^{*} \sqrt{ }(2 \mathrm{MSE} / \mathrm{r})
$$

Rawi \& Khalafalla, 1980)

where $t^{\prime}$ is the $t$ value from "minimum-averagerisk t-table" at F-value of genotypes, genotypes $\mathrm{df}$ and experimental error $\mathrm{df}$. Stress susceptibility index (SSI) was calculated according to the method of Fischer \& Maurer (1978).

Yield of individual genotype was determined under stress (Yl) (late planting) and favorable (Ye) (early planting) conditions. Average yield of all genotypes under late (Xl) and early conditions $(\mathrm{Xe})$ were used to calculate stress intensity (D) as:

$$
\mathrm{D}=1-\mathrm{Xl} / \mathrm{Xe}
$$

The mean stress susceptibility index (SSI) of individual genotype was calculated as:

$$
\mathrm{SSI}=(1-\mathrm{Yl} / \mathrm{Ye}) / \mathrm{D}
$$

Genotypes with average susceptibility or resistance to stress have "SSI" value of 1.0, values less than 1.0 indicate less susceptibility and great resistance to drought. Meanwhile, a value of SSI = 0.0 indicates maximum possible stress resistance (no effect of stress on yield). The diallel analysis was performed as outlined by Hayman (1954) and described by Mather \& Jinks (1971)

\section{Results and Discussion}

Mean seed cotton yield/plant of the parents (Table 2) ranged from 66.33 for (G.87 extra-long) to 125.77 for (G90 $\times$ Aus) with an average of $95.88 \mathrm{~g}$ under early planting, and from 56.33 to 105.87 for (G90× Aus) with an average of $78.64 \mathrm{~g}$ under late planting. Otherwise, the range of seed cotton yield/ plant of the crosses was narrower than that in the parents, either under early or under late planting. Under early planting, the hybrids of seed cotton yield/plant ranged from 52.47 to 106.80 with an average of $75.55 \mathrm{~g}$, and from 47.13 to 86.80 with an average of $61.76 \mathrm{~g}$ under late planting.
The reduction $\%$ in seed cotton yield/plant caused by the stress of late planting was $17.98 \%$ for the parents, and $18.25 \%$ for the crosses. Mohamed et al. (2009) noted reduction in seed cotton yield/plant of 42 and $37.4 \%$ for the parents and crosses; respectively, evaluated under optimum and drought conditions. Pettigrew \& Meredith (2009) pointed to the adverse effects of late sowing on yield and fibers of cotton. The decrease in yield caused by late planting reached $29.79,30.79$ and $27.20 \%$ for females, males and crosses; respectively (Abdalla, 2014).

The results of SSI indicated that five parents (G.90x Aus, G.87, G.86, G.80 and G.45) were tolerant for $\mathrm{SCY} / \mathrm{P}$ to late planting. Fifteen out of the 28 hybrids showed tolerance in SCY/P to late planting. The tolerant hybrids originated from one or both tolerant parents. These hybrids are promising to isolate new lines tolerant in SCY/P to late planting.

The reduction in boll weight reached 20.13 and $15.91 \%$ for the parents and hybrids; respectively. Mean of number of bolls/plant (Table 2) under early and late planting were comparable, and the reduction $\%$ in the parents was negative $(-2.65)$.

Mean number of seeds/boll under late planting of the parental lines ranged from 16.43 for G.95 to 20.09 for G.45 with an average of $18.12 \mathrm{~g}$, and the reduction was $2.16 \%$. The range of the $\mathrm{F} 1$ - hybrids was 16.35 for G. $87 \times$ G. 45 to 20.19 for G. $80 \times$ G.45 with an average of $18.19 \mathrm{~g}$, and the reduction was $3.50 \%$. This is due to that the reduction $\%$ in boll weight of the parents was larger than that in seed cotton yield/plant. Furthermore, the reduction $\%$ in number of bolls/plant of the F1 hybrids was small (2.97\%). The mean number of bolls of the parents ranged from 24.64 for G.92 to 46.67 for G. $90 \times$ Aus, and from 18.30 for G. $87 \times$ G. 86 to 35.95 for G. $95 \times$ G. 90 hybrid.

Mean seed index (Table 3) of the parental lines under early planting ranged from 9.30 to 10.87 with an average of $9.98 \mathrm{~g}$ and from 8.07 to 9.30 with an average of $8.50 \mathrm{~g}$ under late planting. Mean seed index of the F1- hybrids under early planting ranged from 8.50 to 10.30 with an average of $9.60 \mathrm{~g}$, and from 7.90 to 9.50 with an average of $8.69 \mathrm{~g}$ under late planting. The reduction $\%$ in the F1's $(9.47 \%)$ was less than that in the parents $(14.82 \%)$ indicated that the hybrids were more stable than the parental lines in seed index. 
TABLE 2. Mean seed cotton yield/plant, boll weight and number of bolls/plant, reduction $\%$ and stress susceptibility index (SSI);season 2016.

\begin{tabular}{|c|c|c|c|c|c|c|c|c|c|c|}
\hline \multirow[t]{2}{*}{ Genotype } & \multicolumn{3}{|c|}{ SCY/P;g } & \multicolumn{4}{|c|}{ BW;g } & \multicolumn{3}{|c|}{$\mathrm{NB} / \mathrm{P}$} \\
\hline & Early & Late & Mean & SSI & Early & Late & Mean & Early & Late & Mean \\
\hline G95 & 103.50 & 77.37 & 90.43 & 1.39 & 3.03 & 2.30 & 2.67 & 34.23 & 33.74 & 33.99 \\
\hline G92 & 77.70 & 61.03 & 69.37 & 1.18 & 3.20 & 2.47 & 2.83 & 24.34 & 24.94 & 24.64 \\
\hline G90 & 113.20 & 91.53 & 102.37 & 1.05 & 3.00 & 2.30 & 2.65 & 37.71 & 39.94 & 38.83 \\
\hline G90 $\times$ & 125.77 & 105.87 & 115.82 & 0.87 & 2.80 & 2.20 & 2.50 & 45.29 & 48.05 & 46.67 \\
\hline G87 & 66.33 & 56.33 & 61.33 & 0.83 & 2.63 & 2.27 & 2.45 & 25.20 & 24.94 & 25.07 \\
\hline G86 & 104.30 & 85.73 & 95.02 & 0.98 & 3.43 & 2.53 & 2.98 & 30.58 & 33.99 & 32.28 \\
\hline G80 & 100.07 & 87.37 & 93.72 & 0.70 & 3.10 & 2.63 & 2.87 & 32.43 & 33.17 & 32.80 \\
\hline G45 & 76.20 & 63.90 & 70.05 & 0.89 & 2.60 & 2.33 & 2.47 & 29.38 & 27.30 & 28.34 \\
\hline Avera & 95.88 & 78.64 & 87.26 & & 2.98 & 2.38 & 2.68 & 32.40 & 33.26 & 32.83 \\
\hline Reduc & & 17.98 & & & & 20.13 & & & -2.65 & \\
\hline G95 & 87.67 & 77.37 & 82.52 & 0.65 & 3.10 & 2.90 & 3.00 & 28.30 & 26.85 & 27.57 \\
\hline G95 & 102.73 & 86.80 & 94.77 & 0.85 & 2.77 & 2.50 & 2.63 & 37.18 & 34.72 & 35.95 \\
\hline $\begin{array}{l}\text { G95 } \times( \\
\text { Aus }\end{array}$ & 104.67 & 84.30 & 94.48 & 1.07 & 3.00 & 2.73 & 2.87 & 35.03 & 30.89 & 32.96 \\
\hline $\mathrm{G} 95 \times \mathrm{G} 87$ & 75.47 & 72.20 & 73.83 & 0.24 & 3.20 & 2.67 & 2.93 & 23.68 & 27.28 & 25.48 \\
\hline G95 & 97.00 & 78.80 & 87.90 & 1.03 & 2.83 & 2.7 & 2.77 & 34.19 & 29.35 & 31.77 \\
\hline G95 & 72.70 & 63.73 & 68.22 & 0.68 & 3.00 & 2.47 & 2.73 & 24.25 & 25.99 & 25.12 \\
\hline G95 & 58.93 & 53.77 & 56.35 & 0.48 & 2.80 & 2.47 & 2.63 & 21.10 & 22.12 & 21.61 \\
\hline G92 $\times$ & 77.87 & 76.13 & 77.00 & 0.12 & 2.90 & 2.50 & 2.70 & 26.91 & 30.44 & 28.68 \\
\hline $\begin{array}{l}\text { G92 }> \\
\text { Aus }\end{array}$ & 99.30 & 60.90 & 80.10 & 2.13 & 2.83 & 2.43 & 2.63 & 35.29 & 25.34 & 30.32 \\
\hline $\mathrm{G} 92 \times \mathrm{G} 87$ & 6 & 48 & 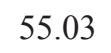 & 1.16 & 2.5 & 2. & 2.60 & 21 & 21.32 & 21.32 \\
\hline G92 & 6237 & 48.50 & 55.43 & 1.22 & 3.00 & 2. & 2.6 & & 21.12 & 21.05 \\
\hline G92 & 54.73 & 49.30 & 52.02 & 0.55 & 2.80 & 2.40 & 2.60 & 19.71 & 20.43 & 20.07 \\
\hline G92 × & 53.77 & 48.17 & 50.97 & 0.57 & 2.93 & 2.23 & 2.58 & & 21.73 & 20.05 \\
\hline $\begin{array}{l}\text { G90 } \times \\
\text { Aus }\end{array}$ & 106.80 & 73.20 & 90.00 & 1.73 & 2.97 & 2.47 & 2.72 & 36.07 & 29.86 & 32.97 \\
\hline $\mathrm{G} 90 \times \mathrm{G} 87$ & 92.07 & 71.80 & 81.93 & 1 & 2. & 2 & 2 & 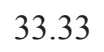 & 07 & 32.70 \\
\hline & & 56.20 & & 1.28 & 3.10 & & 2.83 & & 21.93 & 22.77 \\
\hline G90 & & 58.53 & 65.52 & 1.06 & 2.73 & & 2.55 & 26.72 & 25.01 & 25.87 \\
\hline G90 $\times$ & 61.80 & 53.23 & 57.52 & 0.76 & 2.77 & & 2.53 & & 23.21 & 22.78 \\
\hline $\begin{array}{l}\text { G90 } \\
\text { G87 }\end{array}$ & 30 & 55 & 6 & 1.50 & 2 & 2 & 2.50 & 1 & 4.66 & 09 \\
\hline $\begin{array}{l}\text { G90 } \\
\text { G86 }\end{array}$ & 74.50 & 57.10 & 0 & 1.29 & 2.73 & 2.23 & 2.48 & 50 & 25.57 & 26.53 \\
\hline & 82.03 & 63.43 & 72.73 & 1.25 & 3.00 & 2.33 & 2.67 & 27.33 & 27.30 & 27.32 \\
\hline & 100.60 & 71.80 & 86.20 & 1.58 & 2.73 & 2.23 & 2.48 & 36.84 & 32.27 & 34.55 \\
\hline & 52.47 & 47.13 & 4 & 0 & 3. & 2 & 2 & 17.53 & 07 & 18 \\
\hline & & & & 0. & 2. & 2. & & & 22.51 & 21.78 \\
\hline & & & 58.22 & 0.81 & 2.83 & 2.2 & 2.5 & 22.35 & 23.65 & 23.00 \\
\hline & & & & 0.91 & 2.93 & 2.4 & 2.7 & & 21.78 & 21.80 \\
\hline & & & & 0.58 & 2.77 & 2.3 & 2.5 & 22.76 & 24.39 & 23.57 \\
\hline & & 56. & 59.92 & 0.68 & 2.87 & 2.47 & 2.6 & 22.34 & 22.69 & 22.51 \\
\hline & & 61.76 & 68.65 & & 2.89 & 2.43 & 2.66 & 26.26 & 25.48 & 25.87 \\
\hline & & 11.78 & & & & 0.4 & & 4.11 & 5.43 & \\
\hline & 12.09 & 15.49 & & & & 0.57 & & 5.32 & 6.93 & \\
\hline Reduction $\%$ & & 18.25 & & & & 15.91 & & & 2.97 & \\
\hline
\end{tabular}


TABLE 3. Mean seed index and number of seeds/boll; season 2016.

\begin{tabular}{|c|c|c|c|c|c|c|}
\hline \multirow[t]{2}{*}{ Genotype } & \multicolumn{3}{|c|}{ SI;g } & \multicolumn{3}{|c|}{ NS/B } \\
\hline & Early & Late & Mean & Early & Late & Mean \\
\hline G95 & 9.50 & 8.77 & 9.13 & 18.83 & 16.43 & 17.63 \\
\hline G92 & 10.27 & 8.20 & 9.23 & 19.86 & 19.87 & 19.86 \\
\hline G90 & 9.87 & 8.23 & 9.05 & 18.67 & 17.72 & 18.19 \\
\hline G90 $\times$ Aus & 9.30 & 8.13 & 8.72 & 18.01 & 16.75 & 17.38 \\
\hline G87 & 9.87 & 8.30 & 9.08 & 18.07 & 18.97 & 18.52 \\
\hline G86 & 10.87 & 9.03 & 9.95 & 19.04 & 17.53 & 18.28 \\
\hline G80 & 10.80 & 9.30 & 10.05 & 17.20 & 17.58 & 17.39 \\
\hline G45 & 9.40 & 8.07 & 8.73 & 18.46 & 20.09 & 19.28 \\
\hline Average & 9.98 & 8.50 & 9.24 & 18.52 & 18.12 & 18.32 \\
\hline Reduction\% & & 14.82 & & & 2.16 & \\
\hline G95 × G92 & 10.03 & 9.50 & 9.77 & 19.26 & 19.18 & 19.22 \\
\hline $\mathrm{G} 95 \times \mathrm{G} 90$ & 9.47 & 9.10 & 9.28 & 17.85 & 17.26 & 17.56 \\
\hline $\begin{array}{l}\text { G95 } \times \text { G90 } \times \\
\text { Aus }\end{array}$ & 8.50 & 7.90 & 8.20 & 21.26 & 21.58 & 21.42 \\
\hline $\mathrm{G} 95 \times \mathrm{G} 87$ & 9.90 & 8.50 & 9.20 & 20.08 & 20.18 & 20.13 \\
\hline $\mathrm{G} 95 \times \mathrm{G} 86$ & 10.30 & 9.37 & 9.83 & 16.57 & 18.52 & 17.55 \\
\hline $\mathrm{G} 95 \times \mathrm{G} 80$ & 10.17 & 8.90 & 9.53 & 18.21 & 17.69 & 17.95 \\
\hline $\mathrm{G} 95 \times \mathrm{G} 45$ & 9.53 & 8.90 & 9.22 & 18.23 & 17.79 & 18.01 \\
\hline $\mathrm{G} 92 \times \mathrm{G} 90$ & 9.57 & 8.30 & 8.93 & 18.83 & 20.51 & 19.67 \\
\hline $\begin{array}{l}\text { G92 } \times \text { G90 } \times \\
\text { Aus }\end{array}$ & 10.23 & 9.17 & 9.70 & 17.58 & 17.11 & 17.35 \\
\hline $\mathrm{G} 92 \times \mathrm{G} 87$ & 9.60 & 8.60 & 9.10 & 20.34 & 18.35 & 19.34 \\
\hline $\mathrm{G} 92 \times \mathrm{G} 86$ & 9.80 & 8.80 & 9.30 & 18.44 & 17.33 & 17.89 \\
\hline $\mathrm{G} 92 \times \mathrm{G} 80$ & 9.63 & 8.50 & 9.07 & 18.06 & 18.33 & 18.20 \\
\hline $\mathrm{G} 92 \times \mathrm{G} 45$ & 9.53 & 8.40 & 8.97 & 20.01 & 18.03 & 19.02 \\
\hline $\begin{array}{l}\text { G90 } \times \text { G90 } \times \\
\text { Aus }\end{array}$ & 9.27 & 8.70 & 8.98 & 19.69 & 18.10 & 18.90 \\
\hline $\mathrm{G} 90 \times \mathrm{G} 87$ & 9.83 & 8.43 & 9.13 & 18.14 & 17.88 & 18.01 \\
\hline $\mathrm{G} 90 \times \mathrm{G} 86$ & 9.70 & 8.83 & 9.27 & 19.66 & 18.82 & 19.24 \\
\hline $\mathrm{G} 90 \times \mathrm{G} 80$ & 9.67 & 8.97 & 9.32 & 17.36 & 16.81 & 17.09 \\
\hline $\mathrm{G} 90 \times \mathrm{G} 45$ & 9.50 & 8.50 & 9.00 & 18.78 & 18.23 & 18.51 \\
\hline $\begin{array}{l}\text { G90 × Aus x } \\
\text { G87 }\end{array}$ & 9.43 & 8.50 & 8.97 & 18.55 & 17.22 & 17.88 \\
\hline $\begin{array}{l}\text { G90 } \times \text { Aus } \times \\
\text { G86 }\end{array}$ & 9.80 & 8.67 & 9.23 & 17.18 & 16.88 & 17.03 \\
\hline $\begin{array}{l}\text { G90 } \times \text { Aus } \times \\
\text { G80 }\end{array}$ & 9.30 & 8.53 & 8.92 & 19.20 & 17.37 & 18.29 \\
\hline $\begin{array}{l}\text { G90 } \times \text { Aus } \times \\
\text { G45 }\end{array}$ & 9.40 & 8.47 & 8.93 & 17.87 & 16.81 & 17.34 \\
\hline $\mathrm{G} 87 \times \mathrm{G} 86$ & 9.30 & 8.53 & 8.92 & 20.59 & 18.54 & 19.56 \\
\hline $\mathrm{G} 87 \times \mathrm{G} 80$ & 9.80 & 9.10 & 9.45 & 19.15 & 17.59 & 18.37 \\
\hline $\mathrm{G} 87 \times \mathrm{G} 45$ & 9.57 & 8.80 & 9.18 & 18.09 & 16.35 & 17.22 \\
\hline $\mathrm{G} 86 \times \mathrm{G} 80$ & 9.33 & 8.67 & 9.00 & 19.00 & 17.85 & 18.42 \\
\hline $\mathrm{G} 86 \times \mathrm{G} 45$ & 9.27 & 8.30 & 8.78 & 19.01 & 18.72 & 18.86 \\
\hline $\mathrm{G} 80 \times \mathrm{G} 45$ & 9.27 & 8.30 & 8.78 & 20.74 & 20.19 & 20.47 \\
\hline Average & 9.60 & 8.69 & 9.14 & 18.85 & 18.19 & 18.52 \\
\hline RLSD0.05 & 0.42 & 0.35 & & & 3.56 & \\
\hline RLSD0.01 & 0.55 & 0.45 & & & 3.03 & \\
\hline Reduction $\%$ & 9.47 & & & 3.50 & & \\
\hline
\end{tabular}


Variance, mean, reduction\% and stress susceptibility index

The analysis of variance (Tables 4 and 5) of seed cotton yield/plant, boll weight, number of bolls/plant, seed index and number of seeds/ boll indicated significant $(\mathrm{p} \leq 0.01)$ differences among genotypes (parents and crosses) except for boll weight and number of seeds/boll under early planting date. Therefore, the diallel analysis was performed for these traits except for boll weight

and number of seeds/boll under early planting.

\section{The diallel analysis of variance}

The analysis of variance was done for the parents, F1- hybrids, and parents + F1- hybrids separately under early and late planting dates (not included). A comparison of the block interaction (Exp.error) for the parental families and for the F1- hybrids of the diallel set, showed insignificant differences between them (with 14 and 54 degrees of freedom). Therefore, EP = $\mathrm{EF} 1$ and both equal to the block interaction (Bt) mean squares for the 36 replicated families of the diallel (Mather \& Jinks, 1971). The block interaction $(\mathrm{Bt})$ was used in estimation of the genetic parameters of all traits. The genotypes mean squares (Tables 4 and 5) was significant $(\mathrm{p} \leq 0.01)$ for seed cotton yield/plant, number of bolls/plant and seed index under early and late planting, except for boll weight and number of seeds/boll which were significant ( $p \leq 0.05$ ) under late planting. The diallel analysis of variance (Tables 4 and 5) indicated significant ( $p$ $\leq 0.01)$ "a" and "b" items for all traits expect for "b" item of seed cotton yield/plant and "a" item for number of seeds/boll under late planting. The significance of " $a$ " and " $b$ " items indicated that both additive and dominance effects of genes were involved in the inheritance of the respective traits. The "b1" item mean square was significant for seed cotton yield/plant and number of bolls/plant under early planting, and seed index under both planting conditions. The "b1" item tests the mean deviations of the F1s from their mid-parental values. It is significant only if the dominance deviations of the genes are predominantly in one direction. The "b2" item was significant for seed cotton yield/plant under early planting, boll weight under late planting, number of bolls and seed index under both planting conditions. The "b2" item tests whether the mean dominance deviations of the F1 from their mid-parental values within each array differs over arrays. It will do so if some parents contain considerably more dominant genes than others. The "b3" item was significant for seed cotton yield/plant under early planting, boll weight under late planting, number of seeds/boll under late planting and number of bolls/plant and seed index under both planting dates. The "b3" component tests the part of dominance deviations that is unique to each F1. This component is equivalent to the specific combining ability of Griffing (1956) and others. These results are in general agreement with those reported by Mahdy (1982 a and b) in a full diallel analysis under two plant densities, and Mohamed et el. (2009) in a study of 6- parent diallel cross under normal and drought stress conditions.

\section{The interpretation of $\mathrm{Wr} / \mathrm{Vr}$ graph}

The graphical analysis of seed cotton yield/ plant is shown in Fig.1 and 2. The regression coefficient of $\mathrm{Wr} / \mathrm{Vr}$ under early planting differed significantly from both of " 1.0 " and zero, and not from both under late planting (Table 4). This indicates that epistatic effects of genes were involved in the inheritance of seed cotton yield/ plant. The regression line intercepted the $\mathrm{Wr}$ axe near the original point under early planting, indicating near complete dominance, which confirmed by the average degree of dominance (1.274) (Table 6). Otherwise, under late planting the intercept of regression line to the Wr axe was negative (-5.449) indicating overdominance. The average degree of dominance (H1/D).5 was 1.885 (Table 6) confirming this result. The parent G.80 was located under the regression line and far from the limiting parabola causing over-dominance. Therefore, it could be concluded that the diallel analysis of variance and graphical analysis indicated that the epistatic gene effects were involved in the inheritance of seed cotton yield/plant.

The diallel analysis of variance of boll weight (Table 4) indicated that, mean squares of the entries was not significant under early condition. Therefore, the diallel analysis was not completed. Under late planting condition the regression coefficient of $\mathrm{Wr} / \mathrm{Vr}$ was negative and significantly $(\mathrm{p} \leq 0.01)$ differed from unity but not from zero indicating the presence of epistatic gene interaction in the inheritance of boll weight. 


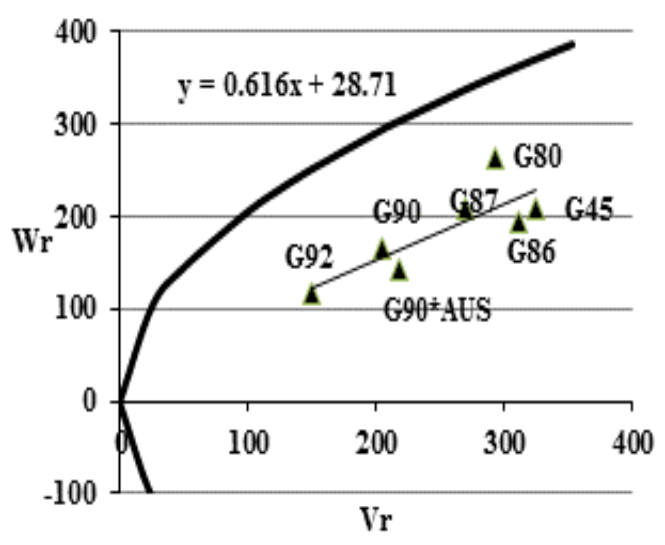

Fig. 1. D1 SCY

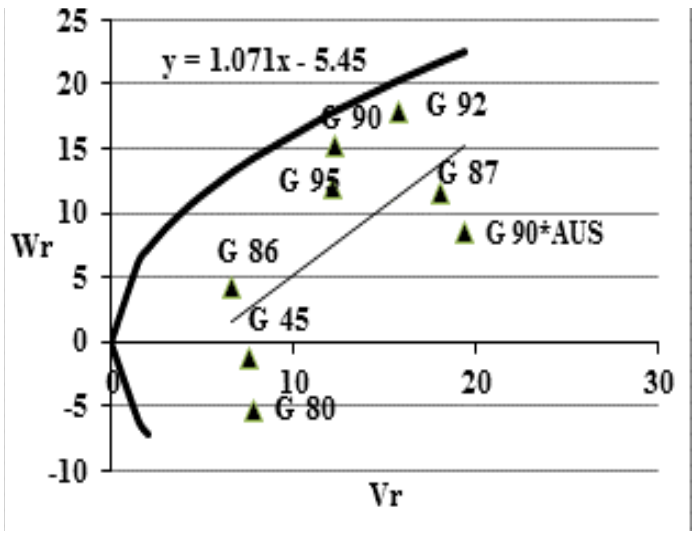

Fig. 2. D2 SCY

TABLE 4. Mean squares of the diallel analysis of variance in the $F_{1}$ - generation at early (D1) and late (D2) planting dates for seed cotton yield/plant, boll weight and number of bolls/plant; season 2016.

\begin{tabular}{|c|c|c|c|c|c|c|}
\hline \multirow[t]{2}{*}{ Item } & \multirow{2}{*}{ df } & \multicolumn{2}{|c|}{ SCY/P;g } & \multirow{2}{*}{$\begin{array}{c}\text { BW;g } \\
\text { D2 }\end{array}$} & \multicolumn{2}{|c|}{$\mathbf{N B} / \mathbf{P}$} \\
\hline & & D1 & D2 & & D1 & D2 \\
\hline Blocks(b) & 2 & 68.73028 & 118.9729 & 0.158148 & 5.890994 & 41.95258 \\
\hline Genotypes & 35 & $1138.449 * *$ & $647.2253 * *$ & $0.080275^{* *}$ & $133.0579 * *$ & $108.6351 * *$ \\
\hline A & 7 & $5589.750 * *$ & $149.6049 * *$ & $0.3291 * *$ & $686.4554 * *$ & $149.6049 * *$ \\
\hline $\mathrm{B}$ & 28 & $893.473 * *$ & 55.8309 & $0.1002 * *$ & $104.0335^{* *}$ & $55.8309 * *$ \\
\hline b1 & 1 & $8684.369 * *$ & 26.7188 & 0.0537 & $789.4461 * *$ & 26.7188 \\
\hline b2 & 7 & $525.878 * *$ & 29.8072 & $0.1448 * *$ & $35.9721 * *$ & $29.8072 *$ \\
\hline b3 & 20 & $632.586 * *$ & 66.3948 & $8.7335^{*}$ & $93.5843 * *$ & $66.3948 * *$ \\
\hline$a * b$ & 14 & 53.8303 & 67.9832 & 0.1003 & 18.1735 & 67.9832 \\
\hline$b * b$ & 56 & 71.7689 & 6.0957 & 6.5879 & 10.4122 & 6.0957 \\
\hline $\mathrm{b} 1 * \mathrm{~b}$ & 2 & 23.3447 & 2.6907 & 7.9090 & 4.1369 & 2.6907 \\
\hline $\mathrm{b} 2 * \mathrm{~b}$ & 14 & 89.1333 & 6.3445 & 6.0245 & 15.8172 & 6.3445 \\
\hline $\mathrm{b} 3 * \mathrm{~b}$ & 40 & 68.1126 & 6.1788 & 7.0750 & 8.8342 & 6.1788 \\
\hline Error(Bt) & 70 & 41.82247 & 60.95687 & 0.040815 & 7.754373 & 12.22428 \\
\hline $\mathrm{r}(\mathrm{p}-, \mathrm{wr}+\mathrm{vr})$ & & 0.073536 & 0.51086 & 0.26033 & 0.44472 & 0.51086 \\
\hline $\mathrm{Wr}+\mathrm{Vr}$ & & Ns & $*$ & ns & ns & $*$ \\
\hline $\mathrm{Wr}-\mathrm{Vr}$ & & Ns & $*$ & ns & ns & $*$ \\
\hline $\begin{array}{l}\text { b from } \\
\text { unity }\end{array}$ & & $*$ & Ns & $* *$ & $*$ & ns \\
\hline $\mathrm{b}$ form 0.0 & & $*$ & Ns & ns & $*$ & ns \\
\hline
\end{tabular}


The graphical analysis of number of bolls/ plant (Fig. 3, 4, 5 and Table 5) indicated partial dominance under early and over-dominance under late planting. The regression coefficient

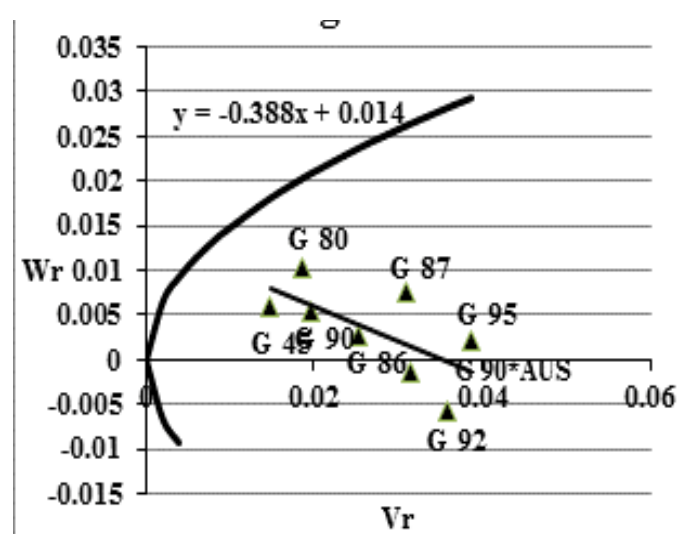

Fig. 3. D2 BY. showed significant difference from unity and zero under early and not significant from both under late planting declaring the presence of epistatic effects of genes controlling number of bolls/plant.

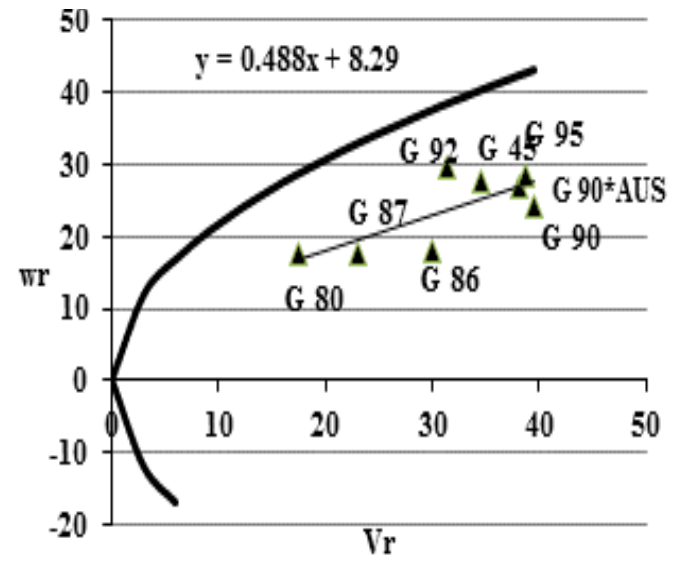

Fig. 4. D1 NB.

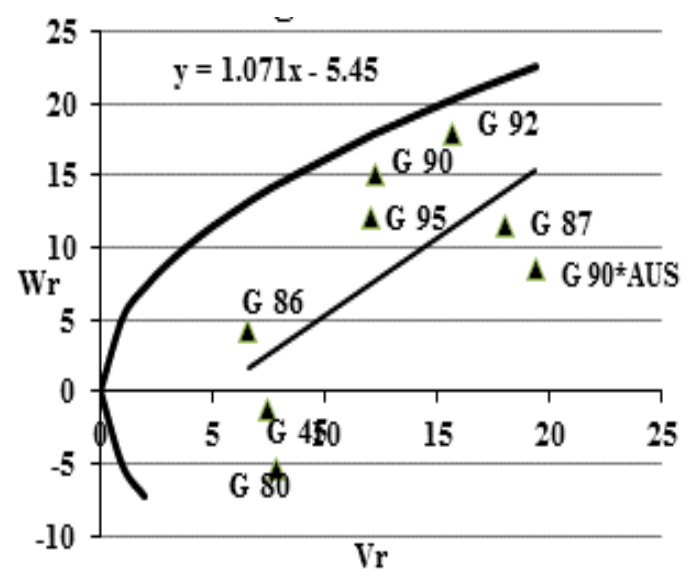

Fig. 5. D2 NB.

The graphical presentation of seed index (Fig. 6, 7 and Table 5) showed that under early planting the regression coefficient of $\mathrm{Wr} / \mathrm{Vr}$ was not significant fromunity, but significant from zero, and $\mathrm{Wr}-\mathrm{Vr}$ mean squares was not significant indicating the adequacy of the additive-dominance model for the data of seed index.

Furthermore, the intercept of the regression line to the $\mathrm{Wr}$ axe was negative and very small (-0.0473) indicating nearly complete dominance. However, under late planting, the regression coefficient was significant from both of zero and unity (Table 5) indicating the presence of non-allelic gene interaction and the inadequacy of additive - dominance model for seed index under late planting.

The graphical presentation of number of seeds/boll (Fig.8) under late planting indicated that the regression coefficient of $\mathrm{Wr} /$ $\mathrm{Vr}$ was not significant from both of zero and unity showing non-allelic gene interaction. It could be concluded that the epistatic gene interactions were involved in the inheritance of seed cotton yield/plant, boll weight, number of bolls / plant under both planting conditions and for seed index and number of seeds/boll under late planting. 
TABLE 5. Mean squares of the diallel analysis of variance in the $F_{1}$ - generation at early (D1) and late (D2) planting dates for seed index and number of seeds/boll; season 2016.

\begin{tabular}{|c|c|c|c|c|}
\hline \multirow[t]{2}{*}{ Item } & \multirow[t]{2}{*}{ df } & \multicolumn{2}{|c|}{ SI;g } & \multirow{2}{*}{$\begin{array}{c}\text { NS /B } \\
\text { D2 }\end{array}$} \\
\hline & & D1 & D2 & \\
\hline Blocks (b) & 2 & 0.095926 & 0.04731 & 5.81 \\
\hline Genotypes & 35 & $0.609235^{* *}$ & $0.43681 * *$ & $4.6605^{*}$ \\
\hline $\mathrm{A}$ & 7 & $1.1902 * *$ & $0.93861 * *$ & 4.3281 \\
\hline B & 28 & $0.8599 * *$ & $0.67529 * *$ & $9.1526^{* *}$ \\
\hline b1 & 1 & $3.1435^{* *}$ & $0.70126^{* *}$ & 0.1041 \\
\hline b2 & 7 & $0.6351 * *$ & $0.34089 * *$ & $6.6056^{*}$ \\
\hline b3 & 20 & $0.8244 * *$ & $0.79103 * *$ & $10.4965^{* *}$ \\
\hline$a * b$ & 14 & 0.1259 & 0.07952 & 7.7193 \\
\hline $\mathrm{b} * \mathrm{~b}$ & 56 & 0.1324 & 0.10004 & 3.8761 \\
\hline $\mathrm{b} 1 * \mathrm{~b}$ & 2 & 0.1597 & 0.01969 & 0.0402 \\
\hline $\mathrm{b} 2 * \mathrm{~b}$ & 14 & 8.5157 & 0.06658 & 3.5200 \\
\hline $\mathrm{b} 3 * \mathrm{~b}$ & 40 & 0.1470 & 0.11578 & 4.1926 \\
\hline Error (Bt) & 70 & 0.075735 & 0.0526 & 2.5743 \\
\hline $\mathrm{r}(\mathrm{p}-, \mathrm{wr}+\mathrm{vr})$ & & 0.0172 & 0.453656 & -0.0160 \\
\hline $\mathrm{Wr}+\mathrm{Vr}$ & & $* *$ & ns & ns \\
\hline $\mathrm{Wr}-\mathrm{Vr}$ & & Ns & $*$ & ns \\
\hline $\mathrm{b}$ from unity & & Ns & ns & ns \\
\hline $\mathrm{b}$ form 0.0 & & $* *$ & ns & ns \\
\hline
\end{tabular}

*,** Significant at 0.05 and 0.01 levels of probability; respectively, $\mathrm{b}$ from unity and from zero is the significant deviation.

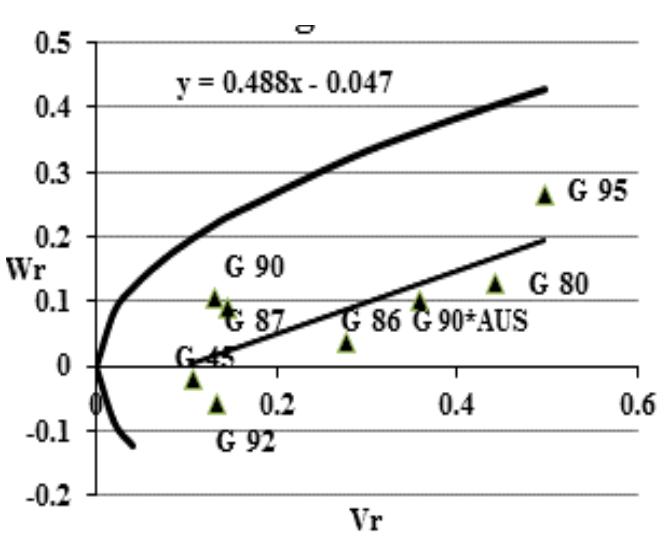

Fig. 6. D1 SI.

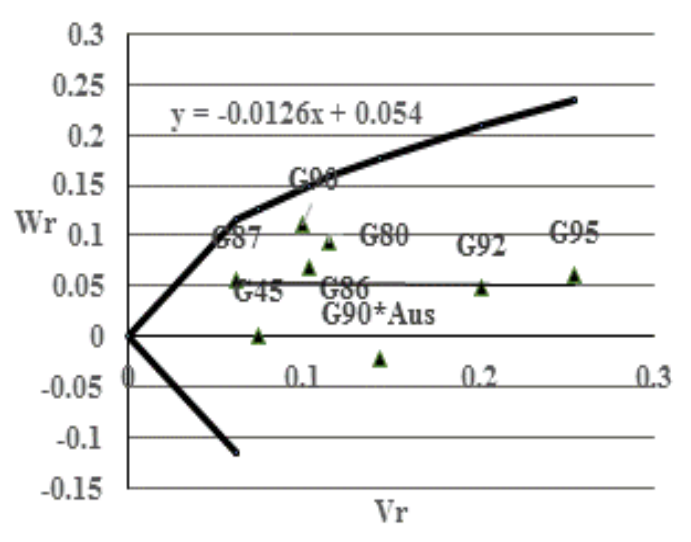

Fig. 7. D2 SI.

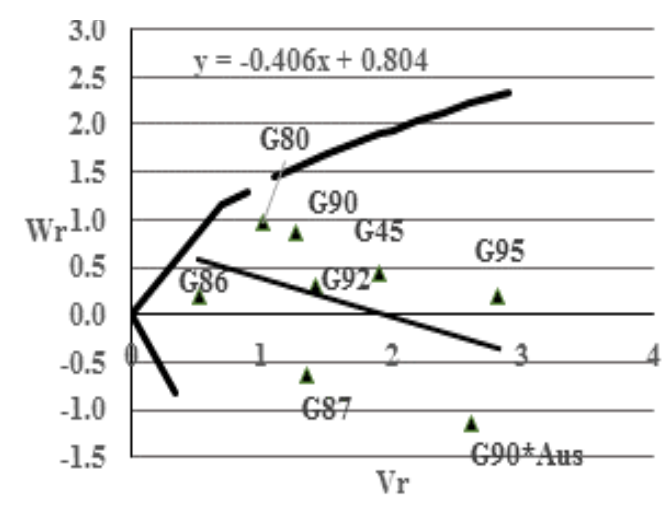

Fig. 8. D2 NS/B 


\section{Genetic parameters}

The results of seed cotton yield/plant under early planting (Table 6) showed that the additive parameter " $D$ " was significant $(\mathrm{p} \leq 0.01)$. Likewise, the dominance parameters "H1" and "H2" were significant $(p \leq 0.01)$. These results indicated that both additive and non-additive effects of genes were involved in the inheritance of seed cotton yield/plant, and this is confirmed by the significant items "a" and "b" (Table 4). The "F" parameter was positive, but not significant from zero. Therefore, two alternatives are possible: either no genes exhibited dominance, or the dominant and recessive alleles were distributed equally among the parents. The former alternative must be rejected because the variance of " $\mathrm{H} 1$ " and or "H2" were significantlydifferent from zero. Therefore, the later explanation must be the correct one. Furthermore, the KD/KR was nearly equal one (1.0459) indicating symmetrical distribution of dominance and recessive genes in the parents. The $\overline{\mathrm{UV}}$ as an estimator of the average frequency of positive showed negative alleles (at loci exhibiting dominance) in the parents, and has a maximum value of 0.25 ; if unequal, it will be smaller. The estimate of UV of seed cotton yield under early planting was (0.2096) and showed slight departure from the theoretical value, and could be considered near the theoretical value $(0.25)$ confirming the results of the insignificant " $F$ " parameter and the ratio $\mathrm{KD} / \mathrm{KR}$. The slight departure of $\mathrm{UV}$ from the theoretical value may cause invalidity estimate of average degree of dominance (1.274) in which the intercept of regression line (Fig. 1) was positive indicating partial dominance. The slight difference between the intercept $(=1 / 4(D-$ $\mathrm{H})$ ) and the average degree of dominance could be caused by two reasons. First, the intercept or $1 / 4(\mathrm{D}-\mathrm{H})$ must be corrected for the environmental component. Second, the departure of UV from its theoretical value invalidates the average degree of dominance (Mather \& Jinks, 1971). The high estimate of $\mathrm{H} 1$ and $\mathrm{H} 2$ respect to the "D" parameter (Table 6) and the significance of regression coefficient of $\mathrm{Wr} / \mathrm{Vr}$ (Table 4) which indicate the presence of non-allelic interaction caused departure of narrow (0.5715) from broad sense heritability $(0.8947)$. The parental mean $(95.88 \mathrm{~g} /$ plant $)$ and the hybrids mean $(75.55 \mathrm{~g} /$ plant) indicated the absence of hybrids vigor in seed cotton yield/plant in this set of diallel crosses.

TABLE 6. Genetic parameters of seed cotton yield/plant, boll weight and number of bolls/plant of the diallel analysis; season 2016.

\begin{tabular}{lccccc}
\hline \multirow{2}{*}{ Item } & \multicolumn{2}{c}{ SCY/P;g } & BW;g & \multicolumn{2}{c}{ NB/P } \\
\cline { 2 - 6 } & D1 & D2 & D2 & D1 & D2 \\
\hline $\mathrm{D} \pm \mathrm{SE}$ & $376.81 \pm 43.62$ & $-34.59 \pm 3.66$ & $-0.0186 \pm 0.0128$ & $38.95 \pm 5.73$ & $14.13 \pm 3.66$ \\
$\mathrm{H} 1 \pm \mathrm{SE}$ & $612.11 \pm 100.28$ & $-122.96 \pm 8.43$ & $-0.0094 \pm 0.0294$ & $57.02 \pm 13.18$ & $11.05 \pm 8.43$ \\
$\mathrm{H} 2 \pm \mathrm{SE}$ & $513.31 \pm 87.24$ & $-82.78 \pm 7.33$ & $-0.0135 \pm 0.0256$ & $54.09 \pm 11.46$ & $13.15 \pm 7.33$ \\
$\mathrm{~F} \pm \mathrm{SE}$ & $21.56 \pm 103.07$ & $-70.08 \pm 8.67$ & $-0.0304 \pm 0.0302$ & $-13.13 \pm 13.54$ & $3.01 \pm 8.67$ \\
$\mathrm{UV}$ & 0.2096 & 0.1683259 & 0.35813 & 0.23713 & 0.29745 \\
$(\mathrm{H} 1 / \mathrm{D})^{1 / 2}$ & 1.274 & 1.885 & 0.711 & 1.209 & 0.884 \\
$\mathrm{~h}^{2}$ & 0.57159 & -0.06165 & 0.17551 & 0.56389 & 0.22543 \\
$\mathrm{H}$ & 0.8947 & -0.6074 & 0.10119 & 0.84106 & 0.38962 \\
$\mathrm{KD} / \mathrm{KR}$ & 1.0459 & 0.3009 & -0.07002 & 0.75545 & 1.2737 \\
Parents mean & 95.88334 & 20.7625 & 2.37916 & 32.3956 & 20.7625 \\
Hybrids & 75.54763 & 21.89049 & 2.42976 & 26.2643 & 21.8904 \\
Mean & & & & & \\
D1 and D2; early and late sowing dates; respectively, $\mathrm{h}^{2}$ and H; narrow and broad sense heritability; respectively. &
\end{tabular}


The genetic parameters of seed cotton yield/ plant under late planting conditions (Table 6) were negative because of the very large experimental error (Table 4). However, the "a" and "b" items were significant indicating the presence of additive and dominance effects. Furthermore, the significant of $\mathrm{Wr}-\mathrm{Vr}$ mean squares, and the insignificance of regression coefficient of $\mathrm{Wr} / \mathrm{Vr}$ from zero indicated non - allelic interaction. Generally, it could be concluded that the inheritance of seed cotton yield/plant under both planting conditions is controlled by additive, dominance and epistatic effects of genes.

The genetic parameters of boll weight under the stress of late planting were negative and insignificant because of the large experimental error. Furthermore, the regression coefficient of $\mathrm{Wr} / \mathrm{Vr}$ was significant $(\mathrm{p} \leq 0.01)$ less than unity indicating that the epistatic genes interaction was operating in the inheritance of boll weight (Table 4). However, mean squares of "a" and "b" items were significant ( $\mathrm{p} \leq 0.01)$. Generally, the results suggested that additive, dominance and epistatic genes interaction were involved in the inheritance of boll weight under the stress of late planting. The large experimental error resulted in unreliable genetic parameters, ratios and estimators.

The genetic parameters of number of bolls/ plant under early and late planting are showed in Table 6. The additive parameters " $D$ " was significant under early and late planting. However, the dominance parameters; H1" and "H2" were significant under early planting only. The " $F$ " parameter was not significant under early planting. The UV (0.2371) was near to the theoretical value, and the average degree of dominance (1.209) indicated overdominance. However, the intercept of the regression line to $\mathrm{Wr}$ axe (Fig. 4) was positive indicating partial dominance. The difference between the two results is mainly due to that the $1 / 4(\mathrm{D}-\mathrm{H})$ (intercept) should be corrected to the environmental component. Under late planting, the UV was not reliable because "H1" showed insignificant difference from zero. In consequence, the $(\mathrm{H} / \mathrm{D})^{1 / 2}$ was not valid.

Narrow sense heritability ranged from (0.2254) under late to (0.5639) under early planting, and broad sense ranged from $(0.3896)$ to $(0.8411)$ under the respective conditions. Estimates of the ratio of dominant to recessive alleles in the parents $(\mathrm{KD} / \mathrm{KR})$ was less than one under early, and more than one under late planting. The regression coefficient of $\mathrm{Wr} / \mathrm{Vr}$ (Table 6) indicated the presence of non-allelic gene interaction under both planting conditions. Parental and hybrid means indicated absence of heterotic effects in number of bolls/plant. Generally, it could be concluded that additive, dominance and epistatic effects of genes were involved in the inheritance of number of bolls/ plant.

The genetic analysis of number of seeds/ boll under late planting (Table 5) indicated insignificace of the additive effects "a item", however, the dominance item "b" was significant $(p \leq 0.01)$ indicating the presence of dominance effects of genes. The analysis of $\mathrm{b} \mathrm{Wr} / \mathrm{Vr}$ indicated the presence of epistatic effects of genes. Furthermore, the four genetic parameters "D, H1, H2 and F" (Table 7) were not significant and the $\mathrm{H} 2$ was larger than $\mathrm{H} 1$ which resulted in UV out of the theoretical limits " 0.25 ", in consequence the average degree of dominance became invalid. Amin et al. (1997), Ajmel et el. (1998) and Shakeel et el. (2001) found over - dominance in the inheritance of these traits. Ahmed et al. (2003) found that seed cotton yield was partially adequate to the additive, dominance model. Nadeem \& Azhar (2004) did not find epistasis in the inheritance of seed cotton yield, number of bolls/ plant and boll weight. The dominance effects of genes were larger in the inheritance of seed cotton yield, number of bolls (Basal \& Turgut, 2005). Rauf et el. (2006) found that specific combining ability was larger than general combining ability in the inheritance of seed cotton yield and number of bolls/plant. Mohamed et al. (2009) indicated non-additive for the same chracters under drought stress and vice versa under favorable conditions. Imran et al. (2012), Kumar et al. (2013), Simon et al. (2013) and Raza et al. (2013) came to the same conclusion. However, Memon et al. (2016) found that the gca variance was larger than that of sca, and the rank order for gca's of the parents differed from F1 to F2 
TABLE 7. Genetic parameters of seed index and number of seeds/boll of the diallel analysis; season 2016.

\begin{tabular}{|c|c|c|c|}
\hline \multirow[t]{2}{*}{ Item } & \multicolumn{2}{|c|}{ SI;g } & \multirow{2}{*}{$\begin{array}{c}\text { NS/B } \\
\text { D2 }\end{array}$} \\
\hline & D1 & D2 & \\
\hline $\mathrm{D} \pm \mathrm{SE}$ & $0.295 \pm 0.0503$ & $0.164 \pm 0.0484$ & $0.672 \pm 1.161$ \\
\hline $\mathrm{H} 1 \pm \mathrm{SE}$ & $0.523 \pm 0.1158$ & $0.390 \pm 0.1114$ & $0.718 \pm 2.670$ \\
\hline $\mathrm{H} 2 \pm \mathrm{SE}$ & $0.424 \pm 0.1007$ & $0.346 \pm 0.0969$ & $1.06 \pm 2.322$ \\
\hline $\mathrm{F} \pm \mathrm{SE}$ & $0.3167 \pm 0.1190$ & $0.145 \pm 0.1145$ & $-0.6601 \pm 2.744$ \\
\hline UV & 0.2024 & 0.22178 & 0.37075 \\
\hline$(\mathrm{H} 1 / \mathrm{D})^{1 / 2}$ & 1.332 & 1.5419 & 1.033 \\
\hline $\mathrm{h}^{2}$ & 0.1765 & 0.1853 & -0.0678 \\
\hline $\mathrm{H}$ & 0.6569 & 0.6920 & 0.0328 \\
\hline $\mathrm{KD} / \mathrm{KR}$ & 2.3490 & 1.8022 & 0.3559 \\
\hline Parents mean & 9.9833 & 8.5041 & 18.116 \\
\hline Hybrids mean & 9.5964 & 8.6869 & 18.187 \\
\hline
\end{tabular}

D1 and D2; early and late sowing dates; respectively, $\mathrm{h}^{2}$ and $\mathrm{H}$; narrow and broad sense heritability; respectively.

\section{References}

Abbas, A., Ali, M.A. and Khan, T.M. (2008) Studies on gene effects of seed cotton yield and its attributes in five American cotton cultivars. J. Agri. Soc. Sci. 4, $147-52$.

Abd El-Bary, A.M.R., Soliman, Y.A.M., Hamoud, H.M.E. and Abou El-Yazied, M.A. (2008) Triallel analysis for yield components and fiber traits in (Gossypium barbadense L.). J. Agric. Sci., Mansoura Univ. 33(2), 1189-1201.

Abdalla, A.M.A. (2014) Factorial cross analysis of yield and earliness in Gossypium barbadense cottons grown on divergent sowing dates. Egypt. J. Plant Breed. 18(4), 607-628.

Ajmel, S.U., Haq, M.I. , Akhtar, M.S. and Sohail, K. (1998) Graphic representation of gene action of some plant characters in Upland cotton. J. Agric. Res. 36, 405-413.

Ahmed, S., Iqbal, M.Z., Hussain, A., Sadiq, M.A. and Jabbar, A. (2003) Gene action and heritability studies in cotton (Gossypium hirsutum L.). J. Biol. Sci. 3(4), $443-450$.

Ali, Samia E.S. (2013) Estimate of some genetic parameters in a cotton cross through north carolina design iii. $J$. Plant Production, Mansoura Univ. 4(2), 313 - 317.

Amin, M.A., Hussain, B. and Rauf, A. (1997) Study of important characters of cotton plant (Gossypium hirsutum L.). J. Agric. Res. 35, 441-446.
Azhar, M.T. and Khan, A.A. (2005) Combining ability analysis of seed cotton yield and its components in cotton (Gossypium hirsutum L.). Pak. J. Sci. and $\mathrm{It}^{\mathrm{s}} \mathrm{ed}$. Res. 48(5): 358-361.

Bange, M.P., Caton S.J. and Milroy, S.P. (2008) Managing yields of high fruit retention in transgenic cotton (Gossypium hirsutum L.) using sowing date. Australian Journal of Agricultural Research, 59, 733-741.

Bange, M.P. and Milroy, S.P. (2004) Growth and dry matter partitioning of diverse cotton genotypes. Field Crops Research, 87(1), 73-87.

Basal, H. and Turgut, I. (2005) Genetic analysis of yield components and fiber strength in upland cotton (Gossypium hirsutum L.). Turkey Asian J. Plant Sci. 4(3):293-298.

Bauer, P.J., May, O.L. and Camberato, J.J. (1998) Planting date and potassium fertility effects on cotton yield and fiber properties. J. Prod. Agric. 11, 415420.

Darweesh, A.H.M. (2010) Genetical studies on triallel crosses in cotton. M.Sc. Thesis, Fac. Agric. Tanta Univ., Egypt.

Dewdar, M.D.H. (2011) Nature of combining abilities and genetic interpretation for some quantitative traits in Egyptian cotton. Bulletin of Faculty of Agriculture, Cairo University, 62(4), 418-424.

El-Kadi, D.A., El-Deeb, A.A., El-Shaarawy, S.A. and 
Abd El-Fattah, H.M. (2011) Triallel analysis for yield and some fiber quality characters in Egyptian cotton. Egypt. J. Plant Breed. 15(3), 213-230.

El- Rawi, K. and Khalafalla, A.M. (1980) "Design and Analysis of Agricultural Experiments". El Mousel Univ., Iraq.

Esmail, R.M., Hendawy, F.A., Rady, N.S. and Hamid, A.M. (1999) Genetic studies on yield and yield components in inter and two intra specific crosses of cotton. Egyptian J. Agron. 21, 37-51.

Fischer, R.A. and Maurer, R. (1978) Drought resistance in spring wheat cultivars. Part 1: Grain yield response. Augt J. Agric. Res. 29, 897-912.

Griffing, B. (1956) Concept of general and specific combining ability in relation to diallel crossing systems. Aust. J. Biol. Sci. 9, 463-493.

Hayman, B.I. (1954) The theory and analysis of diallel crosses. Genetics, 39, 789-809.

Hayman, B.I. (1958) The theory and analysis of diallel crosses II. Genetics, 43, 63-85.

Imran, M., Shakeel, A., Azhar, F.M., Farooq, J., Saleem, M.F., Saeed, A., Nazeer, W., Riaz, M., Naeem, M. and Javaid, A. (2012) Combining ability analysis for within-boll yield components in upland cotton (Gossypium hirsutum L.). Genet. Mol. Res. 11(3), 2790-2800.

Iqbal, M.Z. and Khan, M.A. (1996) Effectiveness of additive dominance for seed and lint indices in Gossypium hirsutum L. Pak. Cotton 40, 64-79.

Jinks, J.L. (1956) The F2 back cross generation from a set of diallel crosses. Heredity, 10, 1-30.

Jinks, J.L. and Hayman, B.I. (1953) The analysis of diallel crosses of Nicotiana rustica varieties. Maize Genet. Newsletter, 27, 48-54.

Khan, A.A., Khan, M.A. and Aziz, K. (1995) Diallel analysis of some agronomic characters in Gossypium hirsutum L. J. Agric. Res. 33, 403-12.

Khan, S.A., Naqib, U.K., Fida, M., Mushtaq, A., Ijaz, A.K., Zarina, B. and Imidad, U.K. (2011) Combining ability analysis in intraspecific F1 diallel cross of upland cotton. Pak. J. Bot. 43(3), 1719-1723.

Kumar, K., Ashokkumar, K. and Ravikesavan, R. (2013) Genetic effects of combining ability studies for yield and fiber quality traits in diallel crosses of Upland cotton (Gossypium hirstum L.). African J. Biotech. 13(1), 119-126.
Luckett, D.J. (1989) Diallel analysis of yield components, fiber quality and bacterial blight resistance using spaced plants of cotton. Euphytica, 44, 11-21.

Mahdy, E.E. (1982a) Genetic parameters under two planting densities in G. barbadense L. 1. Lint yield, number of bolls/plant and boll weight. Assiut $J$. Agric. Sci. 13(6), 195-207.

Mahdy, E.E. (1982b) Genetic parameters under two planting densities in $G$. barbadense L. 11. Lint percent, lint index and seed index. Assiut J. Agric. Sci. 13(6), 209-223.

Mather, K. and Jinks, J.L. (1971) "Introduction to Biometrical Genetics". Cornell University Press, New York, pp. 231.

Memon, M.E.J., Kumbhar, M.B., Rind, M.I., Keerio, M and Memon, S. (2016) Combining ability estimates for yield and fiber quality parameters in Gossypium hirsutum L. Hybrids. J. Basic Applied Sciences, 12, 53-58.

Mohamed, G.I.A., Abd-El-Halem, S.H.M. and Ibrahim, E.M.A. (2009) A genetic analysis of yield and its components of Egyptian cotton (Gossypium barbadense L.) under divergent environments. American-Eurasian J. Agric. Environ. Sci. 5(1), 05-13.

Mohammed, L.I. (2010) Gene action and heterosis of Line X Tester in cotton. Iraqi J. Agric. Sci. 41(5), 67-79.

Mukhtar, M.S., Khan, T.M. and Khan, A.S. (2000) Genetic analysis of yield and yield components in various crosses of cotton (Gossypium hirsutum L.). Int. J. Agric. Biol. 2, 258-60.

Nadeem, K. and Azhar, F.M. (2004) Genetic analysis of seed cotton yield and its components in Gossypium hirsutum L. Int. J. Agric. Biol. 6(5), 865-868.

Palv, S.M. (2009) Heterosis and combining ability for fiber properties in upland cotton (Gossypium hirsutum, L.). Indian J. Agric. Sci. 79(9), 732-734.

Pettigrew, W.T. and Meredith, W.R. (2009) Seed quality and planting date effects on cotton lint yield, yield components, and fiber quality. JCS, 13, 37.

Rauf, S., Munir, H., Basra, S.M.A. and Abdullojon, E. (2006) Combining ability analysis in upland cotton (Gossypium hirsutum L.). International Journal of Agriculture \& Bılogy, 8(3), 341-343.

Raza, M.M., Munawar, M., Hammad, G., Aslam, R., 
Habib, S. and Latif, A. (2013) Genetic analysis of some metric plant traits in Upland cotton (Gossypium hirsutum L.) through hybridization. Universal.J. Plant Sci. 1(1), 1-7.

Said, S.E.R.N. (2011) Genetical studies on double crosses in cotton. Ph.D. Thesis, Agron. Fac. Agric., Al-Azhar Univ., Egypt.

Shakeel, A., Khan, I.A. and Azhar, F.M. (2001) Study pertaining to the estimation of gene action controlling yield and related traits in Upland cotton. Online J. Bio. Sci. 1, 67-70.

Simon, S.Y., Kadams, A.M. and Aliyu, B. (2013) Combining ability analysis in F1 hybrids of cotton (Gossypium species.) by diallel method in northeastern Nigeria. Greener J. Agric. Sci. Nigeria, 3(2), 90-96.

Soomro, Z.A., Larik, A.S., Kumbhar, M.B. and
Khan, N.U. (2006) Expression of heterosis in the F1 generation of a diallel cross of diverse cotton genotypes. Sarhad J. Agric., Pak. 22(3), 427-431.

Steel, R.G.D. and Torrie, J.H. (1980) "Principle and Procedures of Statistics. A Biometrical Approach" $2^{\text {nd }}$ ed., McGraw-Hill Book Company, New York. U.S.A.

Waqar, I., Khan, I.A., , Khan, A.I., , Shah, S.S.M. and Afzal, M. (2015) Genetic analysis of morphological traits in Upland cotton (Gossypium hirsutum L.). Sci. Letters, 3(2), 57-61.

Zangi, M.R., Jelodar, N.B., Kazemitabar, S.K. and Vafaei-tabar, M. (2009) Cytoplasmic and combining ability on fiber quality traits in intra and inter specific crosses of tetraploid cotton. (Gossypium hirsutum L. x Gossypium barbadense L.). Am-Euras J. Agric. Environ. Sci. 5(4), 519-525.

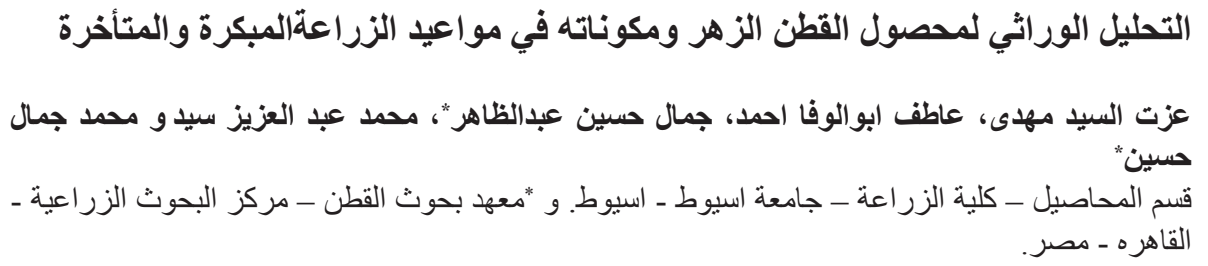

أجريت هذه التجربة لدر اسة تأثير ميعادي الزر اعة المبكر والمتأخر على أداء القطن المصري وطبيعة فعل الجين

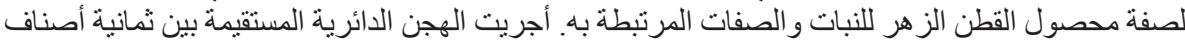

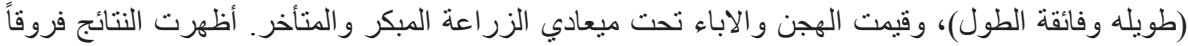

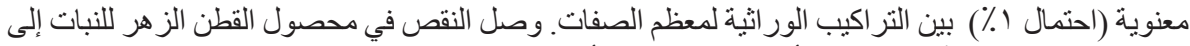
ل

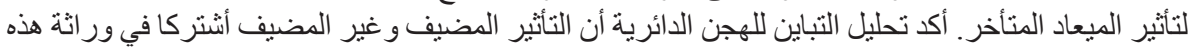

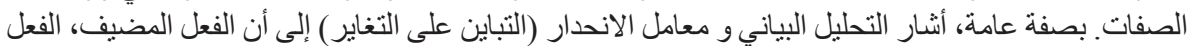

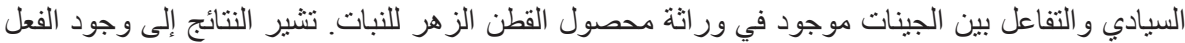

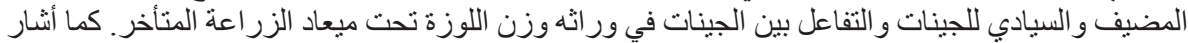

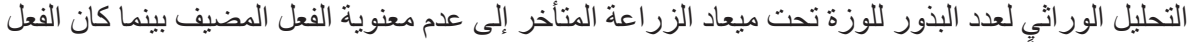

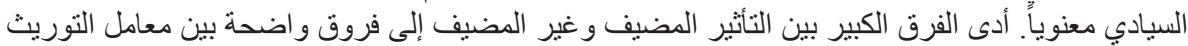

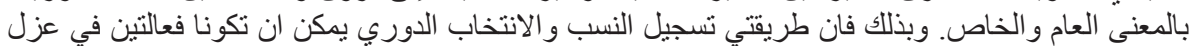

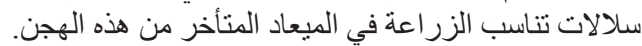

